\title{
Influence of Coiling Temperature on Microstructure, Precipitation Behaviors and Mechanical Properties of a Low Carbon Ti Micro-Alloyed Steel
}

\author{
Mingxue Sun ${ }^{1, *}$, Yang $\mathrm{Xu}^{1}$ and Wenbo $\mathrm{Du}^{2}$ \\ 1 School of Mechanical and Automotive Engineering, Qingdao University of Technology, \\ Qingdao 266520, China; xy45269026@gmail.com \\ 2 National Key Laboratory for Remanufacturing, Academy of Army Armored Forces, Beijing 100072, China; \\ dwbneu@163.com \\ * Correspondence: sunmingxue@qut.edu.cn; Tel.: +86-532-6805-2755
}

Received: 27 July 2020; Accepted: 22 August 2020; Published: 1 September 2020

\begin{abstract}
The microstructural evolution, nanosized precipitation behaviors and mechanical properties of a Ti-bearing micro-alloyed steel at different coiling temperatures were studied using optical microstructure $(\mathrm{OM})$, scanning electron micrograph (SEM), transmission electron microscopy (TEM), Vickers hardness and tensile tests. When the coiling temperature was $500{ }^{\circ} \mathrm{C}$, the specimen showed mainly bainitic structure, whereas polygonal ferrite was visible as the coiling temperature increased to $650{ }^{\circ} \mathrm{C}$ and $700{ }^{\circ} \mathrm{C}$. The Vickers hardness of tested steel reached the maximum, which can be attributed to the largest number of nanosized precipitates in ferrite at the coiling temperature of $650{ }^{\circ} \mathrm{C}$. A coiling temperature of $650^{\circ} \mathrm{C}$ was optimal for the formation of $\mathrm{TiC}$ because of the high diffusion rate of alloying elements and kinetics of precipitation. In the laboratory rolling experiment, when the coiling temperature was $630^{\circ} \mathrm{C}$, the steel with yield strength of $682 \pm 2.1 \mathrm{MPa}$ and tensile strength of $742 \pm 4.9 \mathrm{MPa}$ was produced. The fine-grain strengthening and precipitation strengthening were $262 \mathrm{MPa}$ and $268 \mathrm{MPa}$, respectively.
\end{abstract}

Keywords: coiling temperature; microhardness; nanosized precipitation; precipitation strengthening

\section{Introduction}

Nanosized precipitation of titanium $(\mathrm{Ti})$, niobium $(\mathrm{Nb})$, molybdenum $(\mathrm{Mo})$ and vanadium $(\mathrm{V})$ carbonitrides has been known to be effective for strengthening high-strength low-alloy (HSLA) steels, which are widely used in industrial equipment, bridge, pipeline and automobile. High strength for micro-alloyed steel is one of the researching hotspots in recent years [1-5]. Ti, Nb, V and Mo elements with individually or combined added have been employed to refine microstructure and enhance precipitation strengthening, which could significantly improve the strength of steel. Previous studies showed that the precipitation could provide more than 300-MPa strength increment based on Orowan mechanism when the particle size was less than $10 \mathrm{~nm}$ [6-11].

With the development of micro-alloyed steels, cost reduction becomes a challenge in industrial production due to the high price of micro alloys. Hence, the addition of Ti has attracted increasing attention as a main micro-alloying element to produce high-strength steel because of its abundant resources and the low price. Some studies have attempted to investigate precipitation behaviors of Ti-bearing steels [10-15]. Funakawa and Shiozaki [1] developed a Ti-Mo-based hot-rolled steel with a yield strength over $700 \mathrm{MPa}$ which was coiled at $620^{\circ} \mathrm{C}$ by use of nanosized (Ti, Mo)C particles in ferrite. Kong [10] and Wang [11] studied the influence of hot-rolling process parameters on the precipitation behaviors of nanosized ( $\mathrm{Ti}, \mathrm{Mo}) \mathrm{C}$ particles and found that uniform distributed particles with nanometer size could be obtained in ferrite based on rolling in recrystallization region. 
$\mathrm{Xu}$ [12] reported that the mechanism between dislocation and precipitates for random precipitation and interphase precipitation of a $\mathrm{Nb}$-Ti micro-alloyed steel which was formed at different coiling temperature, was different. Natarajan [15] studied the effect of microstructural evolution, precipitation behaviors and dislocation structure at two coiling temperature in a Nb-Ti high-strength steel. The results showed that there was insufficient time for the dissolved microalloying elements to precipitate during cooling process at high cooling rate, so precipitates mainly formed during coiling stages. Furthermore, in most of the reported literature, the volume fraction of precipitates was artificially determined by transmission electron micrograph (TEM) and the precipitation strengthening was calculated according to theoretical model $[16,17]$. Therefore, detailed investigation on precipitation behaviors at different coiling temperatures should be conducted in Ti micro-alloyed steels.

In this study, the effect of coiling temperature on the microstructure and precipitation behavior of a Ti-bearing micro-alloyed steel was investigated. The optimum precipitation temperature was confirmed by Vickers hardness and TEM. Meanwhile, strengthening mechanism was discussed at hot-rolled condition. The findings from the present study are expected to provide some technical supports for the development of high-strength hot-rolled steels.

\section{Experimental Procedure}

The chemical composition of the tested steel was C 0.05, Si 0.39, Mn 1.5, Ti 0.2, P 0.005, S 0.002, $\mathrm{N} 0.005$ and Fe balance (mass\%). The steel was prepared by vacuum melting and forged into billets with a size of $80 \mathrm{~mm} \times 80 \mathrm{~mm} \times 120 \mathrm{~mm}$, which were then used for hot-rolling experiments. The billets were rolled into $12 \mathrm{~mm}$ in thickness by use of a $\Phi 450 \mathrm{~mm}$ mill of the state key laboratory of rolling and automation (Shenyang, China). The plates were soaked at $1200{ }^{\circ} \mathrm{C}$ for $24 \mathrm{~h}$ followed by water quenching in order to homogenize the micro-alloying elements. Specimens for thermal simulation experiments were cut from the plates along the rolling direction and then machined into a dimension of $\Phi 8 \mathrm{~mm} \times 15 \mathrm{~mm}$.

Thermal simulation experiments were conducted on a Gleeble 3800 thermal simulation machine (DSI, Poestenkill, NY, USA). As shown in Figure 1, the specimens were heated to $1200{ }^{\circ} \mathrm{C}$ with a heating rate of $10^{\circ} \mathrm{C} / \mathrm{s}$ and held for $300 \mathrm{~s}$ to homogenize the micro-alloyed elements and dissolve carbonitrides. The specimens were then cooled with a cooling rate of $10^{\circ} \mathrm{C} / \mathrm{s}$ to 1050 and $850{ }^{\circ} \mathrm{C}$ to be deformed by 0.3 with a strain rate of $5 / \mathrm{s}$. After deformation, specimens were cooled to $700,650,600,550$ and $500{ }^{\circ} \mathrm{C}$ with a cooling rate of $10^{\circ} \mathrm{C} / \mathrm{s}$ and then cooled to room temperature at a cooling rate of $0.1^{\circ} \mathrm{C} / \mathrm{s}$ to simulate the coiling process.

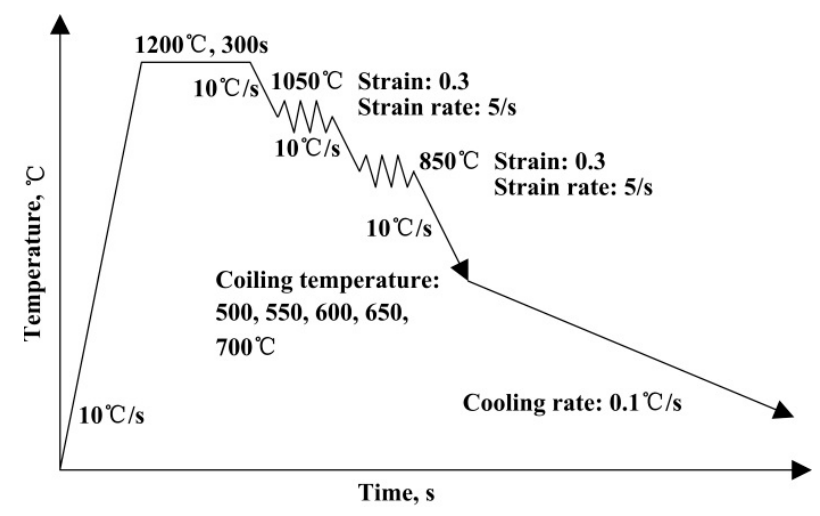

Figure 1. Schedule of thermal simulation experiments.

Hot-rolling experiments were carried out on a $\Phi 450 \mathrm{~mm}$ mill with a variety of cooling devices. The billets for hot rolling were isothermally treated at $1200{ }^{\circ} \mathrm{C}$ for two hours in a $\mathrm{K} 010$ box-shaped furnace, then rolled to $4 \mathrm{~mm}$ through nine-pass rolling. Rolling process was carried out in two stages (roughing rolling and finish rolling). The corresponding rolling reduction was $80 \%$ and 
$75 \%$, respectively. The reduction schedule was: 80-53-36-24-16-12-9-7-5-4 (mm). The billet was rough-rolled through four-pass rolling with average reduction of $33 \%$ and deformation temperature in the range $1100-1050^{\circ} \mathrm{C}$. The intermediate billet was rolled to the desired thin strips through five-pass rolling with average reduction of $24 \%$ and finish rolling temperature in the range $870-850{ }^{\circ} \mathrm{C}$. Finally, the product was laminar cooled with a cooling rate of $20^{\circ} \mathrm{C} / \mathrm{s}$ to $630^{\circ} \mathrm{C}$ and then put into the asbestos (which was used in fire protection and insulation, because of its fiber strength and heat resistance) to cool to room temperature.

Samples for optical metallography of the thermal simulation experiments were cut by wire cutting along the radial direction, while samples for hot-rolling experiments were cut along the perpendicular to the rolling direction. Microstructures of the thermal simulation experiments were observed by use of a LEICAQ550 metalloscope (LEICA Microsystems, Wetzlar, Germany) after etched with $4 \%$ nital. A QUANTA 600 SEM (FEI, Hillsboro, United States) was used to observe the microstructure of the hot-rolled specimen, which was polished and etched using $4 \%$ nital solution. Vickers hardness of different processes was detected with a load of $50 \mathrm{~g}$ and a load time of $10 \mathrm{~s}$. Ten measurements were made on each sample.

Specimens for tensile experiments were cut from hot-rolled slabs along the rolling direction and then machined to the dimension according to the GB/T2975 standard, as shown in Figure 2. Tensile strength, yield strength and elongation were obtained on a CMT-5105 tensile testing machine (MTS, Shenzhen, China) at ambient temperature, and the tensile rate was $5 \mathrm{~mm} / \mathrm{min}$. Three tensile experiments were conducted per condition.

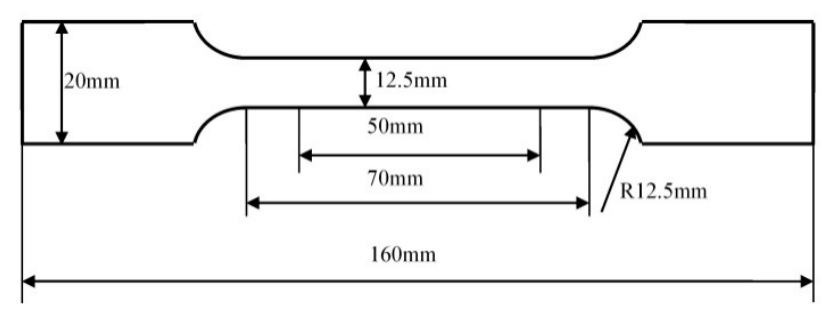

Figure 2. Dimension of specimens for tensile experiments.

Carbon replica and thin foil for TEM observation were prepared to analyze the microstructure of precipitates. Specimens for carbon replicas were cut from the thermal simulation samples along the radial direction. Qualitative analysis of precipitates was performed using an energy-dispersive spectrometer (EDS). The specimen of the hot-rolled steel for TEM was cut into a thickness of $0.5 \mathrm{~mm}$ along perpendicular to the rolling direction, mechanically thinned to $0.05 \mathrm{~mm}$ by abrasion $\mathrm{SiC}$ papers and then twin-jet electro polished to perforation using a mixture of $20 \%$ perchloric acid and $80 \%$ ethanol at $-20{ }^{\circ} \mathrm{C}$, using a potential of $35 \mathrm{~V}$. The characterization of precipitates was carried out on a TecnaiG2 F20 field-emission-gun TEM (FEI, Hillsboro, OR, USA).

\section{Results and Discussion}

\subsection{Optical Metallography}

The optical microstructures of the tested steel at different coiling temperatures during thermal simulation experiment are shown in Figure 3. The microstructure was composed of granular bainite (GB) and acicular ferrite (AF) when coiled at 500, 550 and $600{ }^{\circ} \mathrm{C}$. The microstructure was mainly polygonal ferrite (PF) when the coiling temperatures were 650 and $700{ }^{\circ} \mathrm{C}$. Bainite and ferrite become finer with the decreasing of coiling temperature. Using a linear interception method, the average ferrite grain sizes at 650 and $700{ }^{\circ} \mathrm{C}$ were measured to be $12.2 \pm 2.2 \mu \mathrm{m}$ and $18.4 \pm 3.7 \mu \mathrm{m}$, respectively. It is important to note that coiling temperature was a significant factor to the microstructural evolution. As the coiling temperature decreased, diffusibility of carbon was reduced, resulting in the inhibition of 
ferrite formation. Further, low coiling temperature which caused larger undercooling, contributes to ferrite grain refinement.
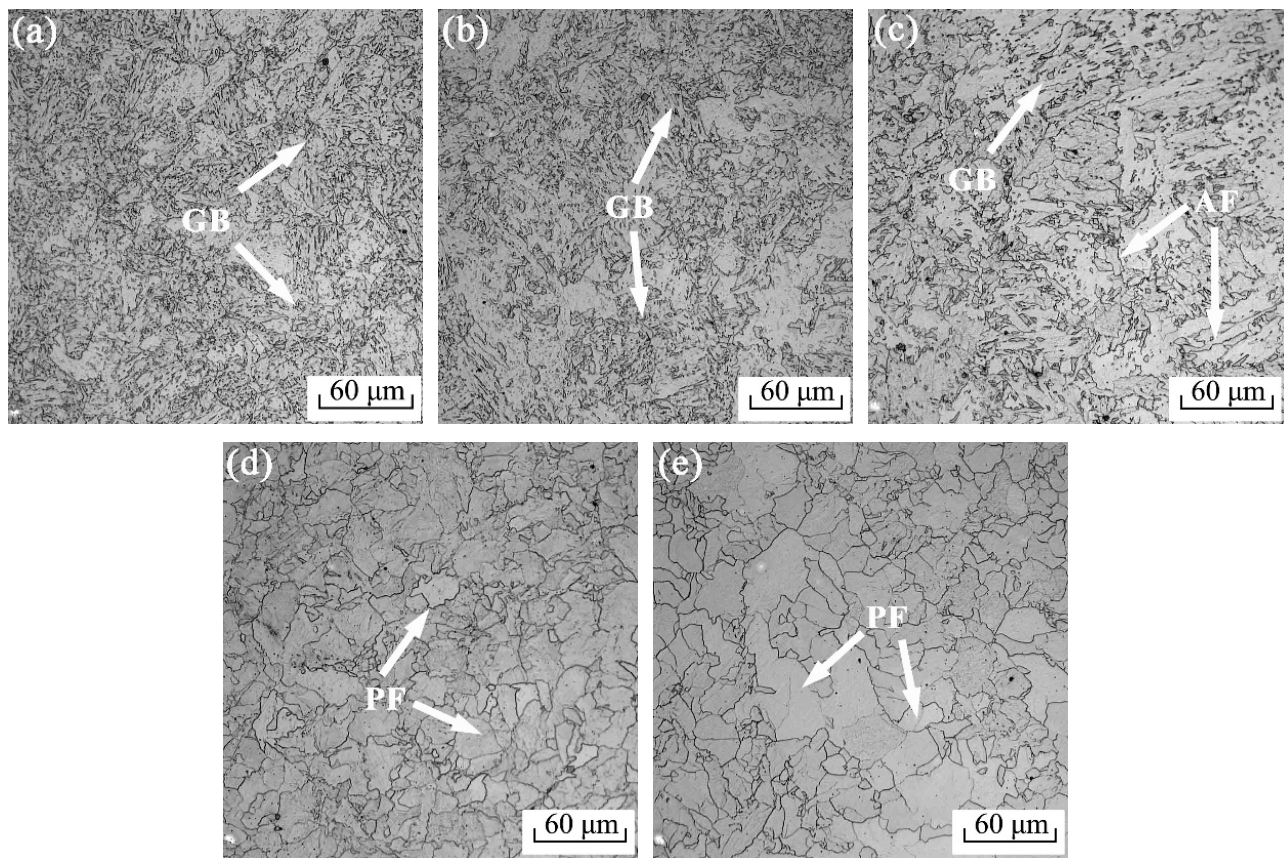

Figure 3. Optical microstructures of tested steel at different coiling temperatures. (a) $500{ }^{\circ} \mathrm{C}$; (b) $550{ }^{\circ} \mathrm{C}$; (c) $600{ }^{\circ} \mathrm{C}$; (d) $650{ }^{\circ} \mathrm{C}$; (e) $700{ }^{\circ} \mathrm{C}$.

\subsection{Vickers Hardness}

Figure 4 shows the variation of Vickers hardness at different coiling temperatures. The Vickers hardness increased with the increasing of coiling temperature from $500^{\circ} \mathrm{C}$ to $650{ }^{\circ} \mathrm{C}$ and rose from $\mathrm{HV}$ $250 \pm 5$ to $\mathrm{HV} 304 \pm 11$. As the coiling temperature increased from $650{ }^{\circ} \mathrm{C}$ to $700{ }^{\circ} \mathrm{C}$, Vickers hardness decreased. In generally, Globular bainite should have a higher hardness than polygonal ferrite. Combining with the microstructural evolution, the higher hardness cannot be obtained when the microstructure was granular bainite at low coiling temperature. The significant difference in Vickers hardness could be mainly attributed to the precipitation strengthening effect due to the addition of Ti. Precipitation behaviors will be discussed to reveal the hardness difference at different coiling temperatures in the following sections.

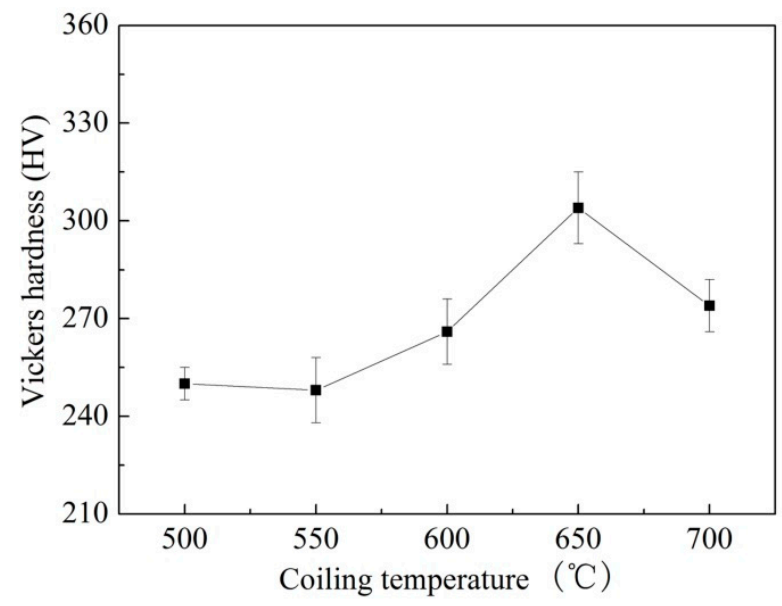

Figure 4. Vickers hardness of the tested steel at different coiling temperatures. 


\subsection{Precipitation Behavior}

In the studied steel, $\mathrm{Ti}$ was added for grain refinement and precipitation strengthening. The characterization of precipitates at different coiling temperatures and EDS results is shown in Figure 5. When the coiling temperature was $500{ }^{\circ} \mathrm{C}$, particles with the size larger than $100 \mathrm{~nm}$ were observed according to the replica technique. With the increasing of coiling temperature, besides the particles with the size larger than $100 \mathrm{~nm}$, increasing particles, which did not exceed $50 \mathrm{~nm}$, could be observed in ferrite. Two representative particles with the size of 200 and $30 \mathrm{~nm}$ were selected for energy spectrum analysis as shown in Figure 5f. The cubic precipitate in Figure 5a and the spherical precipitates in Figure $5 \mathrm{~d}$ were confirmed by EDS analysis to be $\mathrm{Ti}(\mathrm{C}, \mathrm{N})$ and $\mathrm{TiC}$, respectively. Nitrogen preferentially precipitates in the form of large TiN particles, which are formed at high temperature. Ti and $\mathrm{C}$ could accumulate by attaching on $\mathrm{TiN}$, thus the formation of $\operatorname{Ti}(\mathrm{N}, \mathrm{C})$ particles occurs during deformation process. In addition to this, it is evident from Figure 5 that the tested steel contains a large number of spherical precipitates in the form of TiC. The solid solubility of $\mathrm{TiN}$ and $\mathrm{TiC}$ precipitation could be expressed in Equation (1) through (3) [4]:

$$
\begin{aligned}
\lg \{[T i][N]\}_{\gamma} & =3.94-15190 / T \\
\lg \{[T i][C]\}_{\gamma} & =5.33-10475 / T \\
\lg \{[T i][C]\}_{\alpha} & =4.40-9575 / T
\end{aligned}
$$

where [Ti], [N] and [C] are the solid solution amount of element $\mathrm{Ti}, \mathrm{N}$ and $\mathrm{C}$ in austenite and ferrite, $T$ is the solid solution temperature, $\gamma$ and $\alpha$ represent austenite and ferrite, respectively. When the samples were soaked at temperature of $1200{ }^{\circ} \mathrm{C}$, the solid solubility of TiN and TiC were calculated as $4.24 \times 10^{-7}$ and $1.65 \times 10^{-2}$. It is indicated that $\mathrm{N}$ almost fully precipitated as TiN at high temperature. Based on precious studies [17], TiN particles could be neglected for the strengthening effect because of their large size. The remaining $\mathrm{Ti}$ of $0.183 \mathrm{wt} \%$ at $1200{ }^{\circ} \mathrm{C}$ mainly precipitated in the form of $\mathrm{TiC}$ precipitation during the subsequent deformation, cooling and coiling process, which had strong effect on strength.
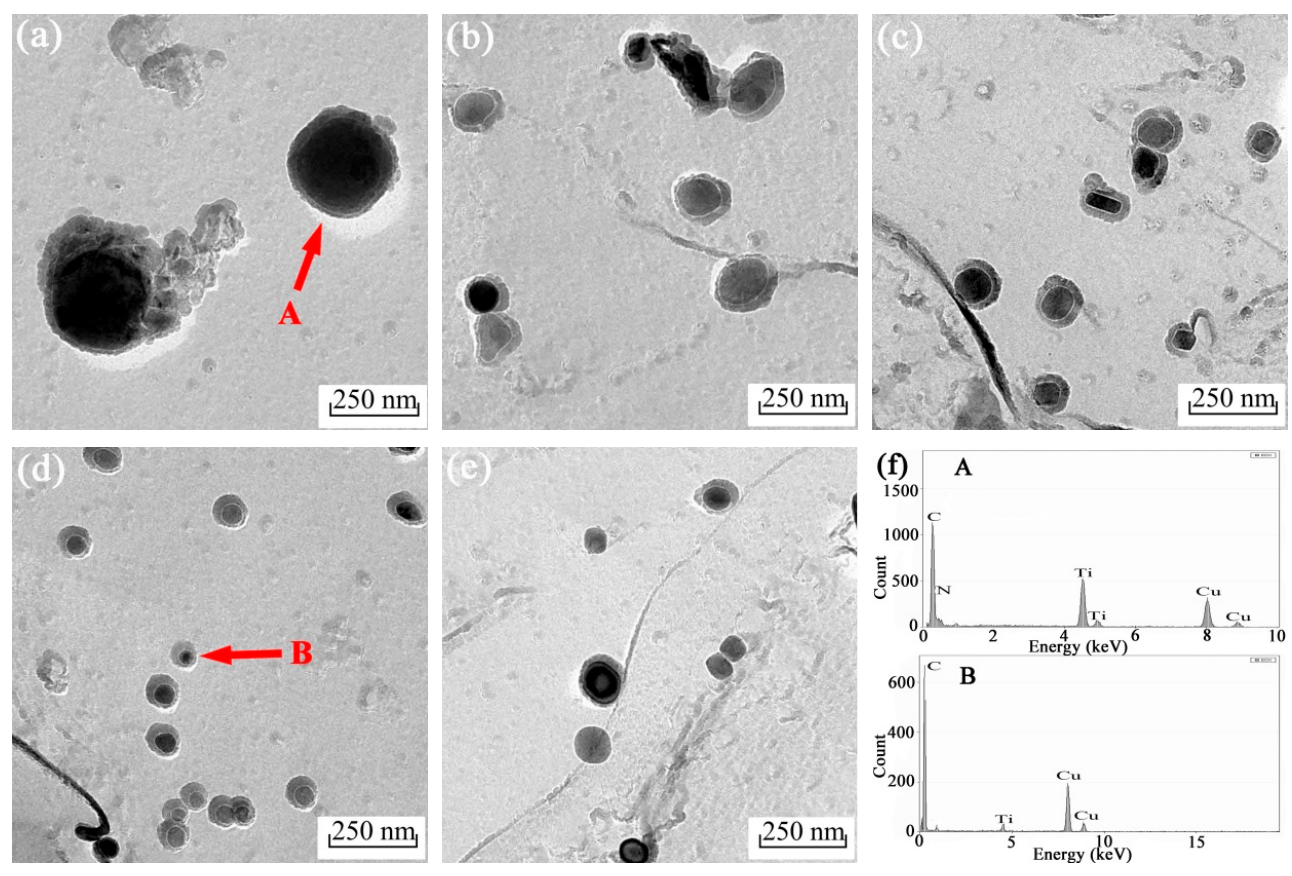

Figure 5. TEM morphologies of precipitates at different coiling temperatures. (a) $500{ }^{\circ} \mathrm{C}$; (b) $550{ }^{\circ} \mathrm{C}$; (c) $600{ }^{\circ} \mathrm{C}$; (d) $650{ }^{\circ} \mathrm{C}$; (e) $700{ }^{\circ} \mathrm{C}$; (f) EDS patterns of different precipitated particles indicated as the red label " $\mathrm{A}$ " in (a) and " $\mathrm{B}$ " in (d). 
Figure 6 presents the size distribution of precipitation for carbon replica specimens at different coiling temperatures. More than eight images were used to determine the size of precipitation using Image-Pro Plus software. It is obvious that when the coiling temperature was $500{ }^{\circ} \mathrm{C}$, the main precipitates were large ones with the size over $100 \mathrm{~nm}$. With the increasing of coiling temperature, the solute Ti became reactive for nucleation, and the volume fraction of small particles increased. When coiled at $650^{\circ} \mathrm{C}$, it is obvious that the TEM morphology is dominated by precipitates with the size less than $50 \mathrm{~nm}$. As the coiling temperature increased to $700{ }^{\circ} \mathrm{C}$, the volume fraction of large precipitates increased, which can be attributed to the coarsening of $\mathrm{TiC}$ precipitates.
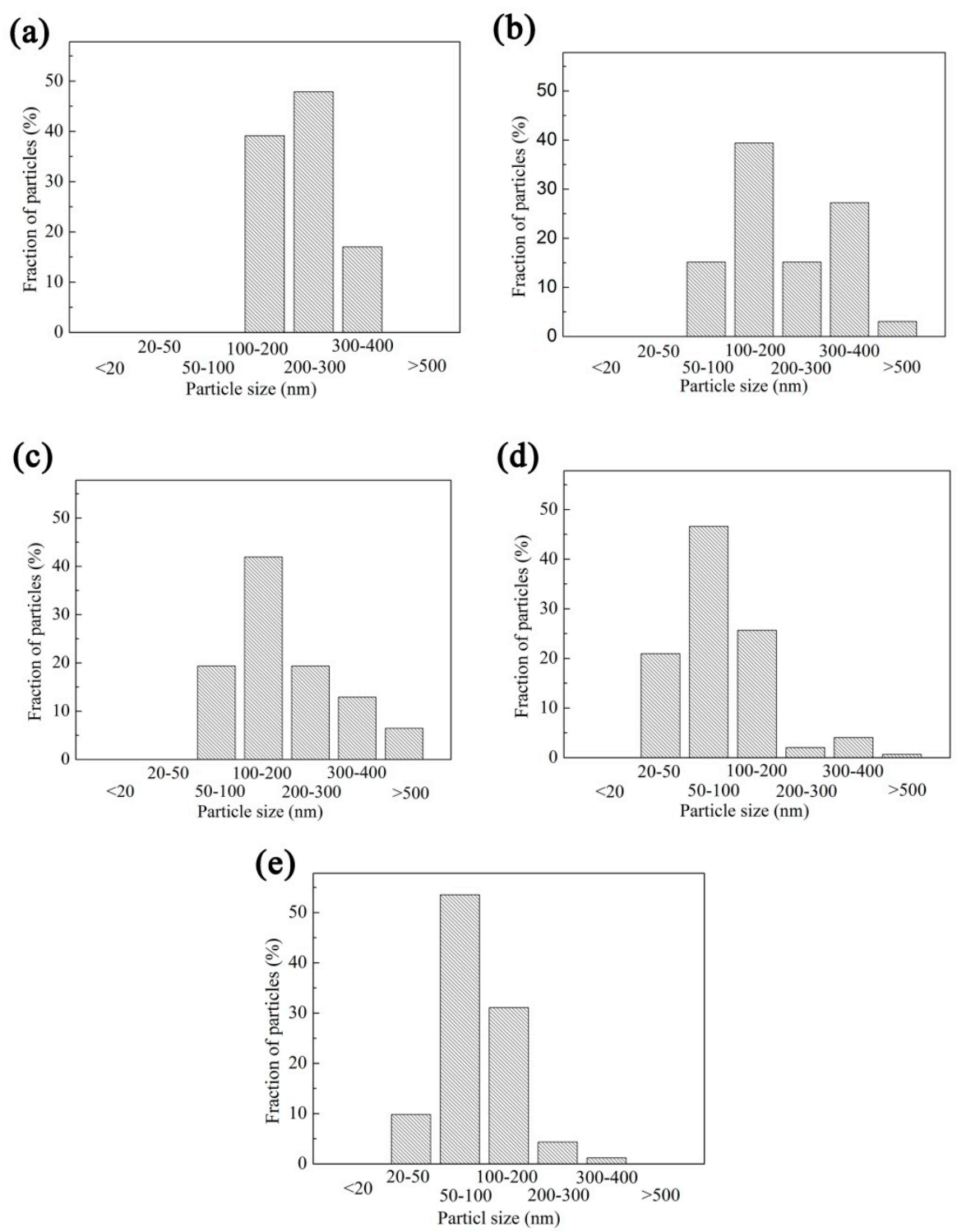

Figure 6. Frequency distribution of precipitates at different coiling temperatures. (a) $500{ }^{\circ} \mathrm{C}$; (b) $550{ }^{\circ} \mathrm{C}$; (c) $600{ }^{\circ} \mathrm{C}$; (d) $650{ }^{\circ} \mathrm{C}$; (e) $700{ }^{\circ} \mathrm{C}$.

According to the classical nucleation theory, nucleation rate can be described in Equation (4) through $(7)[4,18]$ :

$$
\begin{aligned}
& J^{*}=N_{V} \beta^{*} Z \exp \left(-\frac{\Delta G^{*}}{k T}\right) \\
& \beta^{*}=\frac{16 \pi \sigma_{T i C-M a t r i x}^{2} D_{M}}{a_{T i C}^{4} \Delta G_{V}^{2}}
\end{aligned}
$$




$$
\begin{gathered}
Z=\frac{V_{a} \Delta G_{V}^{2}}{8 \pi\left(k T \sigma_{\text {TiC-Matrix }}^{3}\right)^{1 / 2}} \\
\Delta G^{*}=\frac{16 \pi \sigma_{\text {TiC-Matrix }}^{3}}{3 \Delta G_{V}^{2}}
\end{gathered}
$$

where $J^{*}$ denotes the nucleation rate of $\mathrm{TiC}, N_{V}$ is the number of potential nucleation sites per unit volume, $\beta^{*}$ is the frequency factor, $\mathrm{Z}$ is the Zeldovich non-equilibrium factor, $\Delta G^{*}$ is the activation energy of nucleation, $k$ is the Boltzmann coefficient, $T$ is the temperature, $\sigma_{\text {TiC-Matrix }}$ is the interfacial energy between TiC and the matrix, $D_{M}$ is the volume diffusion coefficient of component $\mathrm{Ti}$ in the matrix, $a_{T i C}$ is the lattice parameter of TiC, $\Delta G_{V}$ is the driving force of nucleation and $V_{a}$ is the atomic volume of a substitutional atom of TiC.

In the present study, the heating temperature and deformation factors were all consistent in thermal simulation experiments. It is concluded that $N_{V}, V_{a}, D_{M}$ and $\sigma_{\text {TiC-Matrix }}$ were all the same. The difference in the precipitation behavior could be attributed to the kinetics of precipitation at different coiling temperatures. The nucleation and coarsening of TiC were depended on the diffusion rate of $\mathrm{Ti}$ and $\mathrm{C}$. As the coiling temperature decreased, atomic diffusion was limited, resulting in the restriction of formation and growth of TiC. Thus, a large number of $\mathrm{Ti}$ and $\mathrm{C}$ atoms were kept in solution at low coiling temperature, while they precipitated in the form of $\mathrm{TiC}$ particles at high coiling temperature. When the coiling temperature increased to $700{ }^{\circ} \mathrm{C}$, the diffusion of $\mathrm{Ti}$ and $\mathrm{C}$ was promoted, which caused a larger size of $\mathrm{TiC}$ particles. On the comparing of the precipitation behavior at different coiling temperatures, it is clear that the largest volume fraction of finer precipitates could be obtained at coiling temperature of $650^{\circ} \mathrm{C}$ for Ti-bearing steels.

Based on previous studies, nanosized precipitates could extremely improve the strength of matrix by impeding the movement of dislocations, which can be described by the Ashby-Orowan model according to the theory of Gladman as shown in Equation (8) [4]:

$$
\Delta \sigma_{p p t}=0.3728 \frac{G b}{1-v} \times \frac{f^{1 / 2}}{d} \ln \left(\frac{1.2 d}{2 b}\right)
$$

where $\Delta \sigma_{p p t}$ denotes the strength increment attributed to precipitation strengthening (MPa), $G$ is the shear modulus and equal to $81,600 \mathrm{MPa}, b$ is the Burgers vector of magnitude $0.246 \mathrm{~nm}, v$ is the Poisson ratio, $f$ is the volume fraction of precipitates, and $d$ represents the diameter of precipitates. According to Equations (8), precipitation strengthening is proportional to the volume fraction and inversely proportional to the size of precipitates. As shown in Figures 5 and 6, with the increasing of coiling temperature, the high volume fraction of finer TiC precipitates was obtained, which could provide larger contribution to the strength. Thus, precipitation strengthening was the highest at the coiling temperature of $650^{\circ} \mathrm{C}$, while it decreased at lower and higher coiling temperature. Since the volume fraction of precipitates was not exactly inferred from the replica technique, the precipitation strengthening could not be precisely calculated by Equation (8). In order to quantitatively analysis the effect of TiC particles on strength increment, a further rolling experiment was conducted.

\subsection{Rolling Experiment}

The rolling process parameters and mechanical properties are shown in Table 1 . The yield strength, tensile strength and elongation were $682 \pm 2.1 \mathrm{MPa}, 742 \pm 4.9 \mathrm{MPa}$ and $24.2 \pm 1.7 \%$, respectively. The SEM and TEM of the tested steel are presented in Figure 7 . The hot-rolled steel predominately consisted of polygonal ferrite and quasi-polygonal ferrite, which is consistent with the thermal simulation experiment. The average diameter of ferrite grain was $4.4 \pm 0.8 \mu \mathrm{m}$ measured by Image-Pro Plus software. It can be concluded that the ferrite grain in hot-rolling process is significant finer than that in thermal simulation experiment, which can be mainly attributed to larger deformation and 
higher cooling rate. There existed many spherical and cell-like nanosized precipitates in ferrite matrix, which were identified to be $\mathrm{TiC}$ in the range of $5-30 \mathrm{~nm}$.

Table 1. Rolling parameters and mechanical properties of the hot-rolled steel.

\begin{tabular}{cccccc}
\hline $\begin{array}{c}\text { Heating Temperature } \\
{ }^{\circ} \mathbf{C}\end{array}$ & $\begin{array}{c}\text { Cooling Rate } \\
{ }^{\circ} \mathbf{C} / \mathbf{s}\end{array}$ & $\begin{array}{c}\text { Coiling Temperature } \\
{ }^{\circ} \mathbf{C}\end{array}$ & $\begin{array}{c}\text { Yield Strength } \\
\mathbf{M P a}\end{array}$ & $\begin{array}{c}\text { Tensile Strength } \\
\mathbf{M P a}\end{array}$ & $\begin{array}{c}\text { Elongation } \\
\mathbf{\%}\end{array}$ \\
\hline 1200 & $20-30$ & 630 & $682 \pm 2.1$ & $742 \pm 4.9$ & $24.2 \pm 1.7$ \\
\hline
\end{tabular}
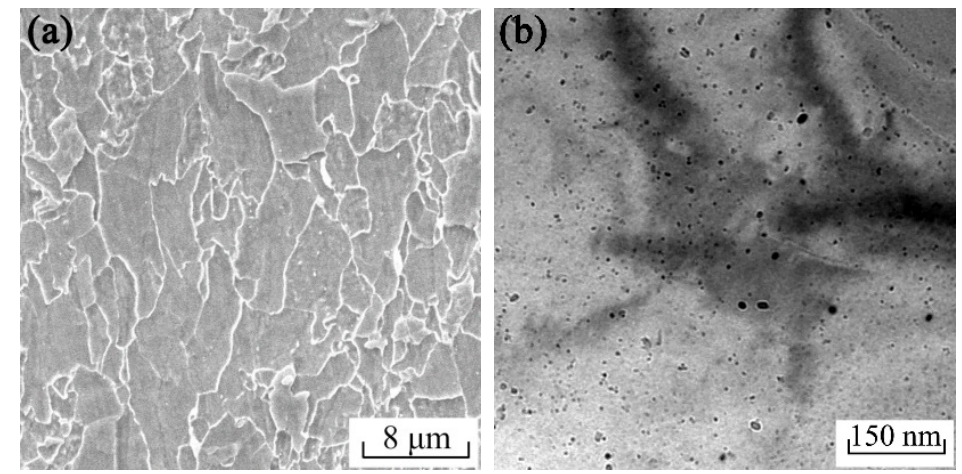

Figure 7. (a) SEM and (b) TEM of the hot-rolled steel.

The yield strength of Ti-bearing steel can be expressed by Equation (9) [19,20]:

$$
\sigma_{y}=\Delta \sigma_{0}+\Delta \sigma_{s s}+\Delta \sigma_{G B}+\sqrt{\Delta \sigma_{d i s}^{2}+\Delta \sigma_{p p t}^{2}}
$$

where $\sigma_{y}$ is the yield strength, $\Delta \sigma_{0}$ is the crystal lattice strengthening (in the present study, the value was assumed to be $54 \mathrm{MPa}$ ), $\Delta \sigma_{S S}$ is the solution strengthening, $\Delta \sigma_{G B}$ is the fine grain strengthening, $\Delta \sigma_{\text {dis }}$ is the dislocation strengthening. The individual contribution of each strengthening mechanism can be evaluated by Equation (10) through (12):

$$
\begin{gathered}
\Delta \sigma_{G B}=17.4 d^{-1 / 2} \\
\Delta \sigma_{S S}=360[C]+32[M n]+83[S i]+700[P] \\
\Delta \sigma_{d i s}=\alpha M G b \rho^{1 / 2}
\end{gathered}
$$

where $d$ is the average size of ferrite grain, $[M](M=C, M n, S i, P)$ is the mass fraction of element $\mathrm{M}$ in solute state, $\rho$ is the dislocation density in per unit area (in present study, the value was assume to be $10^{13} \mathrm{~m}^{-2}$ ), $\alpha$ is equal to $0.38, M$ is the Taylor factor and equals to 2.2 for ferrite grain. The grain refinement strengthening and precipitation strengthening values were calculated as $262 \mathrm{MPa}$ and $268 \mathrm{MPa}$. Although, bainite and acicular ferrite were not obtained at high coiling temperature, the tested steel exhibited high yield strength owing to the grain refinement strengthening and precipitation strengthening because of the Ti addition.

\section{Conclusions}

(1) The samples were composed of granular bainite and acicular ferrite at coiling temperature of 500,550 and $600{ }^{\circ} \mathrm{C}$, while mainly polygonal ferrite was observed at 650 and $700^{\circ} \mathrm{C}$. Coiling temperature has a significant effect on the microstructure evolution and grain size for Ti-bearing steels.

(2) Coiling temperature had an important influence on Vickers hardness attributed to TiC particles. Vickers hardness was the highest at coiling temperature of $650{ }^{\circ} \mathrm{C}$. 
(3) The nucleation rate of $\mathrm{TiC}$ was depended on the diffusion rate of $\mathrm{Ti}$ and $\mathrm{C}$, which was determined by coiling temperature. A large volume fraction of fine $\mathrm{TiC}$ particles could be formed in ferrite at the optimal coiling temperature of $650{ }^{\circ} \mathrm{C}$.

(4) In the hot-rolling condition, yield strength and tensile strength were $682 \pm 2.1 \mathrm{MPa}$ and $742 \pm 4.9 \mathrm{MPa}$, respectively. The intense precipitation strengthening effect increased the yield strength by $268 \mathrm{MPa}$ attributed to the large number of nanosized TiC precipitates in ferrite.

Author Contributions: Conceptualization, M.S. and Y.X.; methodology, M.S.; software, Y.X.; validation, Y.X.; formal analysis, Y.X.; investigation, M.S.; resources, Y.X.; data curation, M.S.; writing-original draft preparation, M.S.; writing-review \& editing, M.S. and W.D.; visualization, M.S.; supervision, Y.X. and W.D.; project administration, Y.X.; funding acquisition, M.S. All authors have read and agreed to the published version of the manuscript.

Funding: This research was funded by the Natural Science Foundation of Shandong Province (ZR2019BEE025 and ZR2019PEE012).

Conflicts of Interest: The authors declare no conflict of interest.

\section{References}

1. Yoshimasa, F.; Tsuyoshi, S. Development of high strength hot-rolled sheet steel consisting of ferrite and nanometer-sized carbides. ISIJ Int. 2004, 44, 1945-1951.

2. Kim, Y.W.; Kim, J.H.; Hong, S.G.; Lee, C.S. Effects of rolling temperature on the microstructure and mechanical properties of Ti-Mo microalloyed hot-rolled high strength steel. Mater. Sci. Eng. A 2014, 605, $244-252$. [CrossRef]

3. Liu, D.S.; Cheng, B.G.; Chen, Y.Y. Strengthening and toughening of a heavy plate steel for shipbuilding with yield strength of approximately $690 \mathrm{MPa}$. Metall. Mater. Trans. A 2013, 44, 440-455. [CrossRef]

4. Yong, Q.L.; Ma, M.T.; Wu, B.R. Microalloy Steel-the Physical and Mechanical Metallurgy; Machinery Industry Press: Beijing, China, 2006.

5. Senuma, T. Present status of future prospect $\mathrm{s} f$ or precipitation research in the steel industry. ISIJ Int. 2002, 4,1-12. [CrossRef]

6. Misra, R.D.K.; Tennetis, K.K.; Weatherly, G.C.; Tither, G. Microstructure and texture of hot-rolled Cb-Ti and $\mathrm{V}-\mathrm{Cb}$ microalloyed steels with differences in formability and toughness. Metall. Mater. Trans. A 2001, 34, 2041-2051. [CrossRef]

7. Craven, A.J.; He, K.; Garvie, L.A.J.; Baker, T.N. Complex heterogeneous precipitation in titanium-niobium microalloyed Al-killed HSLA steels-(Ti, Nb)(C, N)particles. Acta Mater. 2000, 48, 3857-3868. [CrossRef]

8. Han, Y.; Shi, J.; Xu, L.; Cao, W.Q.; Dong, H. TiC precipitation induced effect on microstructure and mechanical properties in low carbon medium manganese steel. Mater. Sci. Eng. A 2011, 530, 643-651. [CrossRef]

9. Kazuhiro, S.; Yoshimasa, F.; Shinjiro, K. Hot rolled high strength steels for suspension and chassis parts “NANOHITEN" and "BHT ${ }^{\circledR}$ steel". JFE Technical. Rep. 2007, 10, 19-25.

10. Sun, C.F.; Cai, Q.W.; Wu, H.B.; Mao, H.Y.; Chen, H.Z. Effect of controlled rolling processing on nanometer-sized carbonitride of Ti-Mo ferrite matrix microalloyed steel. Acta Metall. Sin. 2012, 48, 1415-1421. [CrossRef]

11. Wang, X.N.; Di, H.S.; Du, L.X. Effects of deformation and cooling rate on nano-scale precipitation in hot-rolled ultra-high strength steel. Acta Metall. Sin. 2012, 48, 621-628. [CrossRef]

12. Xu, Y.; Zhang, W.N.; Sun, M.X.; Yi, H.L.; Liu, Z.Y. The blocking effects of interphase precipitationon dislocations' movement in Ti-bearing micro-alloyed steels. Mater. Lett. 2015, 139, 177-181. [CrossRef]

13. Xu, L.X.; Wu, H.B.; Tang, Q.B. Effects of Coiling Temperature on microstructure and precipitation behavior in $\mathrm{Nb}-\mathrm{Ti}$ microalloyed steels. ISIJ Int. 2018, 58, 1086-1093. [CrossRef]

14. Xu, Y.; Sun, M.X.; Zhou, Y.L.; Liu, Z.Y.; Wang, G.D. Effect of Mo on nano-precipitation behavior and microscopic mechanical characteristics of ferrite. Steel Res. Int. 2015, 86, 1056-1062. [CrossRef]

15. Natarajan, V.V.; Challa, V.S.A.; Misra, R.D.K. The determining impact of coiling temperature on the microstructure and mechanical properties of a Titanium-Niobium ultrahigh strength microalloyed steel: Competing effects of precipitation and bainite. Mater. Sci. Eng. A 2016, 665, 1-9. [CrossRef]

16. Xu, Y.; Sun, M.X.; Yi, H.L.; Liu, Z.Y. Precipitation behavior of $(\mathrm{Nb}, \mathrm{Ti}) \mathrm{C}$ in coiling process and its effect on micro-mechanical characteristics of ferrite. Acta Metal. Sin. 2015, 51, 31-39. 
17. Gan, X.L.; Yuan, Q.; Zhao, G.; Ma, H.W.; Liang, W.; Xue, Z.L.; Qiao, W.W.; Xu, G. Quantitative analysis of microstructures and strength of $\mathrm{Nb}$-Ti microalloyed steel with different Ti additions. Metall. Mater. Trans. A 2020, 51, 2084-2096. [CrossRef]

18. Toshio, M.; Hitoshi, H.; Goro, M.; Tadashi, F. Effects of ferrite growth rate on interphase boundary precipitation in V microalloyed steels. ISIJ Int. 2012, 52, 616-625.

19. Jose, C.M.; Guillermo, E.; Estela, P.T. Characterization of microalloy precipitates in the austenitic range of high strength low alloy steels. Steel Res. 2002, 73, 340-345.

20. Yen, H.W.; Chen, P.Y.; Huang, C.Y.; Yang, J.R. Interphase precipitation of nanometer-sized carbides in a titanium-molybdenum-bearing low-carbon steel. Acta Mater. 2011, 59, 6264-6274. [CrossRef]

(C) 2020 by the authors. Licensee MDPI, Basel, Switzerland. This article is an open access article distributed under the terms and conditions of the Creative Commons Attribution (CC BY) license (http://creativecommons.org/licenses/by/4.0/). 